\title{
NOVEJŠI TRENDI V GEOGRAFSKEM RAZISKOVANJU PRSTI IN RASTLINSTVA V SLOVENIJI IN V TUJINI
}

\author{
Ana Vovk Korže \\ Dr., Oddelek za geografijo, Pedagoška fakulteta Univerze v Mariboru, \\ Koroška cesta 160, 2000 Maribor, Slovenija. \\ e-mail: ana.vovk@uni-mb.si
}

\begin{abstract}
Izvleček
$\mathrm{V}$ prispevku je prikazana geografska metodologija preučevanja prsti in vegetacije v slovenskih učbenikih, knjigah, atlasih in leksikonih ter učnih načrtih fakultetnih programov geografije. S pregledom teh virov želimo podati oceno, kaj, kako in s kakšnimi rezultati sta zastopani geografija prsti in vegetacije $\mathrm{v}$ slovenski geografiji in izven nje. Za lažjo primerjavo smo vključili trende geografskega raziskovanja prsti in vegetacije tudi $\mathrm{v}$ sosednjih državah. V tujini imajo specializirane revije in strokovna združenja za razvoj na področju geografije prsti in rastlinstva. Pomembno je spoznanje, kako konkurenčno je naše znanje, $v$ katero smer ga razvijamo in ter katero lastno raziskovalno metodologijo smo razvili v Sloveniji in jo tudi objavili v mednarodnih revijah.
\end{abstract}

Ključne besede: fizična geografija, geografija prsti, biogeografija, predmetniki geografije, ekologija.

\section{RECENT TRENDS IN GEOGRAPHICAL RESEARCH OF SOIL AND VEGETATION IN SLOVENIA AND ABROAD}

\begin{abstract}
Geographical research methodology of soil and vegetation in Slovenian publications (books, textbooks, lexicons, atlases, and the existing geography curricula in university programmes) is presented in this article. By reviewing these resources, we would like to evaluate how and with what results is soil and vegetation geography presented in Slovenia. Trends in geographical research of soil and vegetation in neighboring countries are also included. Abroad, there are many specialized periodicals and professional associations concerned with developing soil and vegetation geography. It is important to establish how competitive our geographical knowledge about vegetation and soil is, and in which direction it needs to be developed. Additionally, we need to establish which research technology has been developed in Slovenia and also published in the international periodicals.
\end{abstract}

Key words: physical geography, soil geography, biogeography, geography curricula, ecology. 